\section{Windows of opportunities and technological innovation in the Brazilian pharmaceutical industry}

Janelas de oportunidades e inovação tecnológica na indústria brasileira de medicamentos

Ventanas de oportunidades e innovación tecnológica en la industria brasileña de medicamentos
Paulo Bastos Tigre 1

Caio Victor Machado França do Nascimento 1 Laís Silveira Costa 2

\begin{abstract}
The Brazilian pharmaceutical industry is heavily dependent on external sources of inputs, capital, and technology. However, the emergence of technological opportunities and the development of biotechnology and the decline of the patent boom and resulting advances by generic drugs have opened windows of opportunities for the local industry. The article examines the Brazilian industry's innovative behavior vis-à-vis these opportunities, showing that although the industry as a whole invests little in innovation, a few large Brazilian companies have expanded their market share and stepped up their investments in research and development, supported by public policies for innovation.
\end{abstract}

Drug Industry; Generic Drugs; Sustainable Development; Innovation

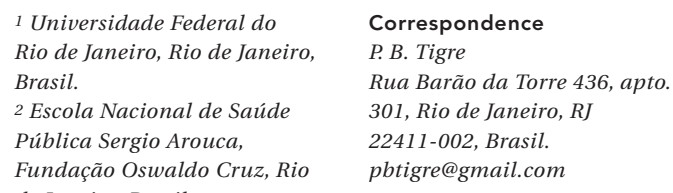

1 Universidade Federal do Rio de Janeiro, Rio de Janeiro, Brasil.

2 Escola Nacional de Saúde Pública Sergio Arouca,

Fundação Oswaldo Cruz, Rio

\author{
Correspondence \\ P. B. Tigre \\ Rua Barão da Torre 436, apto. \\ 301, Rio de Janeiro, $R J$ \\ 22411-002, Brasil. \\ pbtigre@gmail.com
} de Janeiro, Brasil. 


\section{Introduction}

Windows of opportunities for innovation emerge in the gaps in existing technological trajectories, creating new needs for capacity-building and innovation 1 . Over the course of a given trajectory, the leading companies have moved ahead on the learning curve and detained tacit knowledge that is very difficult to be reproduced by new entrants, thereby raising strong entry barriers. However, disruptive technological changes can alter the capabilities and knowledge needed to innovate and produce, opening opportunities for companies specialized in the new technologies 2 . In the pharmaceutical industry, the development of a biotechnology-based trajectory represents an unique opportunity for companies and research organizations that have not achieved success in fine chemicals in the past, but have recently succeeded in establishing their capability in biopharmaceuticals.

For latecomers to the technological race, another opportunity is patent expiration, opening the way for generics. The pharmaceutical patent boom peaked in the late 20th century, in the wake of the Agreement on Trade-Related Aspects of Intellectual Property Rights (TRIPS). However, the last 20 years have witnessed a gradual decrease in the rate of introduction of new molecules 3 , resulting in an increase in the share of generics on the market. In Brazil, adherence to the pipeline mechanism brought into the country's legal system the patents that were filed abroad but could not be granted under the previous legislation 4 . This procedure had postponed the development of generics in Brazil for several years, but there is now a significant growth in the share of generics, along with an increasing market share for laboratories with Brazilian capital.

The purpose of this article is to analyze how Brazilian companies and research organizations have taken advantage of such opportunities to innovate and increase their market share. Is access to knowledge derived from expired patents contributing to process improvements and an increase in the production scale, making internal research and development (R\&D) activities feasible for these companies? National companies sustain that hypothesis, but some authors argue that production of generics will generate an environment of accommodation, harmful to technological innovation 5 .

Brazilian companies and laboratories have also shown growing interest in biopharmaceuticals. However, it is worth verifying whether Brazil's domestic industry is taking full advantage of the fact that such knowledge is still in the initial phase of development, in order to innovate.
The study was built upon qualitative and quantitative secondary data. A review of the recent literature examined the innovation processes in biopharmaceuticals and the role of the dissemination of generics in the Brazilian industry's innovative behavior. Other data sources were the last two editions (2008 and 2011) of the Survey on Industrial Technological Innovation by the Brazilian Institute of Geography and Statistics (PINTEC/IBGE).

PINTEC uses internationally consolidated methodologies from the Oslo Manual of the Organization for Economic Cooperation and Development 6 (OECD), thus allowing international comparisons. We should mention the limitations of this research source. Although the industry data have been more extensively disaggregated since the survey in 2008, separating the pharmaceutical and fine chemicals industries, they still fail to present the desirable segmentation in medicines for human versus veterinary use and the pharmaceutical preparations that entail distinct technological challenges. The survey also fails to capture the industry's innovations resulting from new health care procedures and structures, but these have a more direct impact on the medical and hospital materials and devices industry, which is beyond the current study's scope. Despite these limitations, the PINTEC is the main indicator of innovative efforts by Brazilian industry and presents a wide range of indicators that can be compared in qualitative studies.

The article consists of five sections, besides the Introduction. The second section discusses recent trends in the Brazilian pharmaceutical industry, emphasizing the role of generics. Next we examine the companies' strategies, innovation rates, and funding sources. The fourth section analyzes the investment profile in innovative activities, highlighting the nature of spending on these activities. The fifth section reviews the main available policy tools for promoting innovation in the industry. We then present some final thoughts and remarks.

\section{Trends and structure of the pharmaceutical industry in Brazil}

The Brazilian pharmaceutical industry is undergoing an important period of expansion and consolidation, with an average annual growth rate around $10 \%$ since 2004 5,7. The sales volume in Brazilian pharmacies alone nearly tripled in the last 10 years, reaching a total turnover of BRL 60 billion in 2013 (Sindicato da Indústria de Produtos Farmacêuticos no Estado de São Paulo. Indicadores econômicos Sindusfarma, 2014 
http://sindusfarma.org.br/cadastro/index.php/ site/ap_indicadores, accessed on 13/Sep/2014). Brazil ranks 6th worldwide in pharmaceutical markets, ahead of other important emerging countries like India and Russia.

However, expansion of the Brazilian market has not been accompanied by a corresponding increase in the supply side. The country shows a growing deficit on the balance of trade for the pharmaceutical sector, mainly resulting from imports of patent-protected products. Approximately $30 \%$ of the national demand for medicines is met by imported products ${ }^{8}$. Despite stepping up policies for the sector's industrial and technological development, the deficit of the Health Economic-Industrial Complex (HEIC) reached US $\$ 11.5$ billion in 2014; medicines accounted for $24 \%$ of this amount and fine chemicals another 23\% (Secretaria de Comércio Exterior, Ministério do Desenvolvimento, Indústria e Comércio Exterior. Aliceweb2. http://aliceweb.mdic.gov.br/, accessed on 19/Feb/2015).

Reflecting a world trend, the upward trend in the domestic pharmaceutical industry is associated with the commercial success of generics. In the last ten years, this segment's share of the Brazilian market increased from $9 \%$ to $27 \%$ in terms of units sold and from $8 \%$ to $24 \%$ in sales value (Sindicato da Indústria de Produtos Farmacêuticos no Estado de São Paulo. Indicadores econômicos Sindusfarma, 2014. http:// sindusfarma.org.br/cadastro/index.php/site/ ap_indicadores, accessed on 13/Sep/2014). As observed internationally, the generics segment is expected to be a driving force in the Brazilian pharmaceutical market, reaching approximately $40 \%$ of all medicines sold in the coming years.

As shown in Table 1, in 2013, six companies with domestic capital ranked among the eleven leading pharmaceutical companies in the country, producing mainly generics and similars.

Brazil also has 21 institutions belonging to universities and the state and federal governments 9,10 . The importance of the network of government laboratories lies in its potential to promote the social orientation of domestic technological development through the production of drugs that are neglected by the private sector $10,11,12$. The network also helps strengthen the country's regulatory capacity by performing tests and essays. It is expected that the manufacturing output of public laboratories will have an impact on price formation, particularly for compounds of continued treatment, favoring a reduction in public expenditures on medicines and helping guarantee access 11,13. In addition, with the existing technological platforms, the network of public laboratories has achieved reasonable self-sufficiency in vaccine production 14

The regulations on generics ( $\operatorname{Law} 9,787 / 1999)$ require a minimum price drop of $35 \%$ in relation to the reference medicines 15 , but in practice the differences are even greater due to competition. Brazilian National Health Regulatory Agency (Anvisa) has already registered generics products comprising more than 500 different active ingredients, totaling more than 30 therapeutic classes, covering prevalent diseases in the Brazilian population, including a major share of the most prevalent chronic diseases. At the international level, generic medicines cover an estimated $95 \%$ of existing diseases 16 .

As provided by the legislation, switching between reference products and generics can be recommended by the pharmacist at the moment of sale, which reinforces price competition. Maintenance of profit margins in this scenario depends on production structures that allow competitive costs, which require organizational, productive, and commercial efficiency standards and production scales typical of large companies. This partly explains the trend towards mergers and acquisitions (M\&A) in Brazil. According to the PINTEC, from 2008 to 2011, the number of companies producing drugs and medicines in Brazil decreased by $7 \%$, from 495 to 458 companies, even while the nominal net sales revenue (NSR) increased by $29 \%$.

From the point of view of innovation, the relevant question for this study is whether the higher scales of production favored by M\&A are actually contributing to changes in Brazilian companies' technological strategies. The next two sections examine this question by highlighting the different sources of knowledge in the industry.

\section{Innovation strategies in the Brazilian pharmaceutical industry}

According to the OECD and IBGE guidelines, innovation is something new for the institution that adopts it, but not necessarily a novelty for the national or international market. Pharmaceutical companies thus innovate by incorporating new and more advanced products, organizational models, equipment, drugs, and information systems than those previously used. By defining innovation technologies as new only for those that adopt them, the statistics bureaus found that, worldwide, very few companies and organizations adopt offensive strategies aimed at developing original innovations.

The increase in the production scale and the incremental innovations generated by the 
Table 1

Eleven largest pharmaceutical companies in Brazil.

\begin{tabular}{|c|c|c|c|}
\hline Company & Origin of capital & Sales revenue in 2013 (US\$ millions) & Main markets \\
\hline Hypermarcas & Brazil & $1,900.2$ & Generics; copies; unethical; consumer \\
\hline Pfizer & United States & $1,532.2$ & Reference drugs; unethical \\
\hline Novartis & Switzerland & $1,098.6$ & Reference drugs; unethical \\
\hline Roche & Switzerland & $1,054.0$ & Reference drugs; unethical \\
\hline EMS Sigma Pharma & Brazil & 809.6 & Generics; copies \\
\hline Eurofarma & Brazil & 738.5 & Generics; copies; unethical \\
\hline Aché & Brazil & 587.3 & Generics; copies; originals; unethical \\
\hline Merck & Germany & 472.2 & Reference; unethical \\
\hline AstraZeneca & United Kingdom/Sweden & 429.6 & Reference; unethical \\
\hline União Química & Brazil & 254.9 & Generics; copies; unethical; veterinarian \\
\hline Teuto & Brazil/United States & 246.6 & Generics; copies; unethical; consumer \\
\hline
\end{tabular}

Source: prepared by the authors based on the list "Maiores empresas do Brazil em 2013" in Exame magazine 49, and information made publically available by the companies listed.

introduction of generics in the product portfolio generally accelerates learning in industrial processes, quality management, and distribution, through "learning by doing". Although generics are copies of innovative medicines with expired patents, their production requires technical capability to meet the rigorous quality control standards demanded by the health regulatory agency. To reach the consumer market, generics need to pass bioequivalence tests in human beings to guarantee that they will be absorbed at the same concentration and rate as the reference medicines, besides the requirement of pharmaceutical equivalence tests.

Table 2 lists the characteristics (scarcely innovative) of Brazil's domestic pharmaceutical industry. A comparison of PINTEC data from 200817 and 201118 shows a nominal increase of only $26 \%$ on spending in innovation, insufficient to maintain investments at $5 \%$ of NSR. In addition to lack of real growth, there was a decline in the number of companies that had introduced new products and processes in the two years prior to the surveys. Such concentration is consistent with the downward trend observed in the number of companies in the pharmaceutical industry that invested resources in innovative activities 19. However, previous editions of the PINTEC show advances in the total volume invested in innovation, both in absolute terms and in relation to NSR, a fact which was not confirmed in the survey's latest edition.

Another important indicator is the innovation rate, or the number of companies that introduced new or substantially new products or processes on the market as a proportion of all the companies surveyed. A comparison of the PINTEC in 2008 and 2011 shows that the innovation rate in the Brazilian pharmaceutical industry dropped from $64 \%$ to $54 \%$, confirming the impression that innovation is concentrating in fewer companies. The data may also reflect a decline in innovation efforts throughout the manufacturing industry following the crisis in 2008.

In the target period, the share of public financing of private internal $R \& D$ activities increased substantially due to federal government policies and measures 8,20. According to data from the PINTEC 17,18, in 2008 approximately $92 \%$ of innovative companies covered the costs of the internal R\&D activities with their own resources, while only $7 \%$ received public funding. By $2011, R \& D$ projects in $17 \%$ of the companies were supported by public funds. Meanwhile, the number of pharmaceutical companies that received public funding for other innovative activities (licensing, training, equipment purchases, etc.) remained stable.

Few companies in Brazil develop intensive R\&D activities, possible because their technical and financial resources are significantly limited when compared to global leading companies. More aggressive innovation strategies are thus relatively rare. Innovations in chemical synthesis are particularly difficult, since the tacit knowledge accumulated by the leading companies over the decades is very difficult to reproduce. However, disruptive new technologies like biotechnology offer opportunities for leapfrogging, or taking advantage of the opportunities generated by 
Fine chemical and pharmaceutical manufacturing companies that implemented product and process innovations.

\begin{tabular}{lccc}
\hline Years & Number of companies & Spending on innovative activities (in BRL billions) & Investment/NSR (\%) \\
\hline 2008 & 301 & 1.5 & 4.9 \\
2011 & 211 & 1.9 & 4.8 \\
Variation (\%) & -30.0 & 26.0 \\
\hline
\end{tabular}

NSR: nominal net sales revenue.

Source: prepared by the authors based on data from Survey on Industrial Technological Innovation (PINTEC) 17,18.

radical innovation to enter cutting-edge technology areas without needing to go through intermediate steps. When disruption occurs on a technological pathway, many of the new capabilities required for production are still in the field of science in which knowledge tends to be more encoded and thus more difficult to transfer.

Biotechnology refers to the application of science and technology to living organisms with the purpose of producing knowledge, goods, or services. Brazil has witnessed growing interest by laboratories in obtaining technological capability for the development and production of biopharmaceuticals, given the expected increase in their use by health systems 21,22. PINTEC 201118 identified 74 companies manufacturing drugs or medicine that implemented innovations or conducted activities in biotechnology. Of this total, 28 pharmaceutical companies were developing internal $R \& D$ activities in biopharmaceuticals (Figure 1).

To enter the biopharmaceuticals market, Brazilian companies have turned to different technology sources. Bionovis entered a technology transfer agreement with Merck to receive the technology underlying a non-new biopharmaceutical product, hereinafter referred to here as a biosimilar, indicated for treatment of rheumatoid arthritis and other chronic inflammatory diseases (Etanercept) 23. Meanwhile Orygen Biotechnology signed a cooperation agreement with a Korean company to develop two biosimilars on the list of strategic products for the Brazilian Unified National Health System (SUS) 24. The Cristália laboratory took a more independent development path, although it also cooperates with external partners, having received a positive evaluation by Anvisa to produce three biosimilars 25 .

The trend suggests that capacity-building for the production of biosimilars is an indispensable stage for the development and production of biopharmaceuticals. Yet the long-term sustainability of this process will require stepping up invest- ments in $R \& D$ and greater participation in global knowledge networks. Biotechnology is a science that is still in the consolidation phase, and there are still many gaps in scientific knowledge, methods for the manipulation of molecules, and adaptation of laboratory techniques to the industrial scale, all of which requires cooperation between companies and universities.

A significant share of Brazil's $R \& D$ efforts involves public laboratories, which have contributed to the development of the necessary competencies for strengthening the production and innovation base in health. In Brazil, the strategy of strengthening the capability for generation, use, and diffusion of new technologies in the last decade acknowledged the need to qualify these laboratories as useful institutions to support regulation, technological capacity-building, and production of strategic inputs for the SUS 11,26 . Thus, an important part of the strategy for domestic industrial capacity-building in health involved modernization of the public laboratories through improvement of the management structure and growing investments in technological capability ${ }^{14}$.

The policy aims to overcome the prevailing bottlenecks in Brazil's domestic industrial base and develop future-bearing technology platforms. Such bottlenecks include the country's marginal participation in the above-mentioned global knowledge networks. The country still lags behind the global technological frontier 27,28 . The effectiveness of Brazilian National Health Innovation System (SNIS) is limited, among other factors, by low communication rate between the organizations and institutions in the SNIS, contrary to the trend in more mature innovation systems 29 . In addition, structural problems in Brazilian society such as extreme inequality, poor quality of education, precarious infrastructure, precarious information technology in the national territory, and an adverse tax system vis-à-vis productivity also affect and limit the capacity to produce and innovate Brazilian health industries 20,30. 


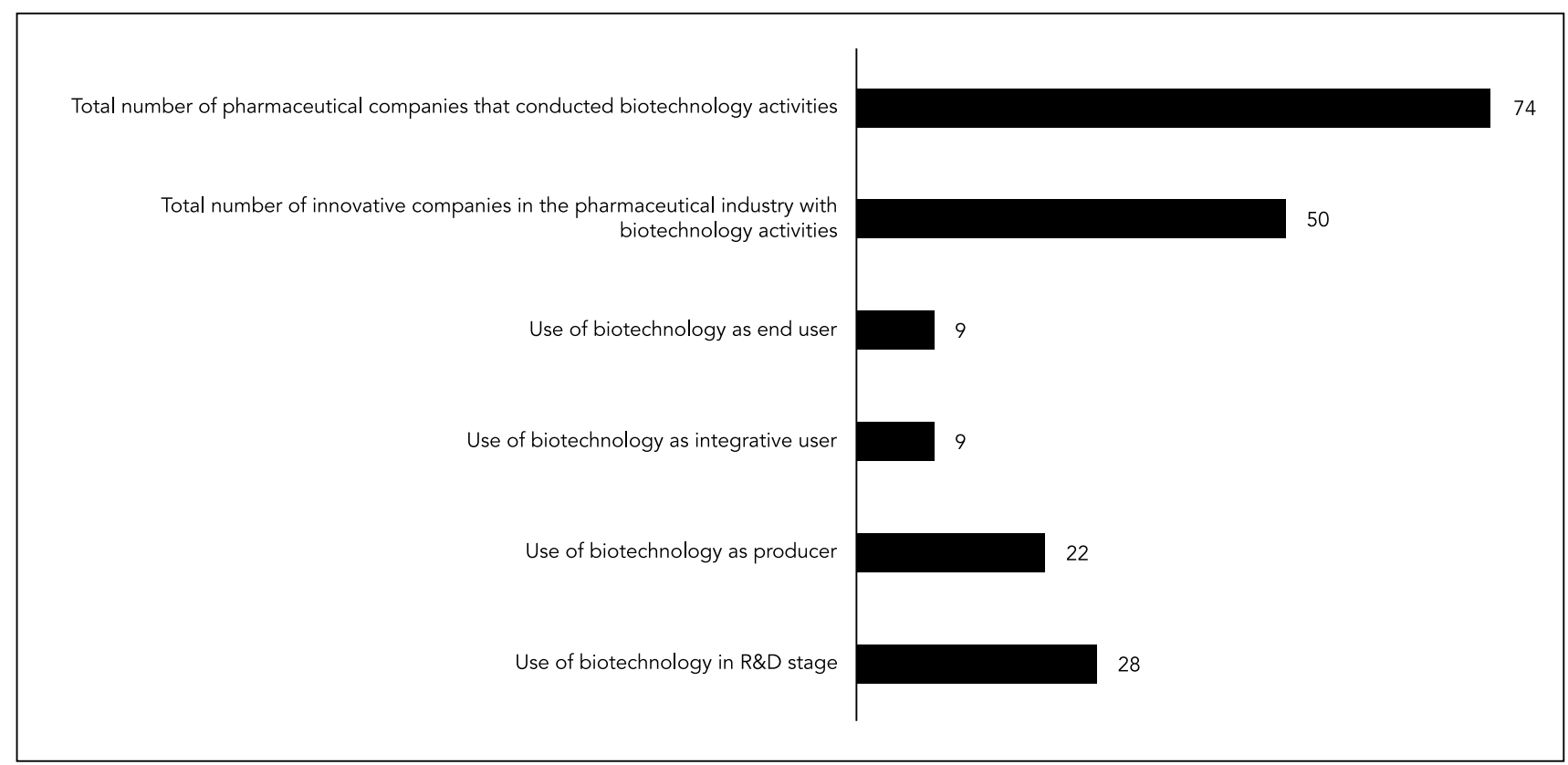

R\&D: research and development.

Source: prepared by the authors based on data from Survey on Industrial Technological Innovation (PINTEC) 201118.

In technological terms, the country has witnessed the growing leadership of biotechnology in the health area, which involves, for example, the use of genetic engineering for the production of biopharmaceuticals, vaccines, and gene therapy, besides the application of pharmacogenetics tools, aimed at the development of more personalized therapies ${ }^{8}$. Recent years have seen various guidelines and policy tools, reflected in an increase in funding for the development of the pharmaceutical sector and the HEIC as a whole, emphasizing the need to implement mechanisms to stimulate health innovation and intensify technology transfer to domestic public laboratories 30 .

\section{Investment profile in innovative activities}

The recent history of the Brazilian pharmaceutical industry shows important changes in the investment profile in innovation. A disaggregated analysis of PINTEC data indicates that companies in this sector have significantly increased internal spending in R\&D (Table 3) when com- pared to other sources of innovation. R\&D efforts are associated directly with technological capability and are the most important indicator of pharmaceutical companies' innovative potential 31. This tendency had already been observed in previous years 19 , but to a lesser extent. Between 2008 and 2011, R\&D spending more than doubled, reaching BRL 920 million, about half of all investments in health innovation. Despite a slight drop in the number of companies that conducted internal R\&D activities, there was an increase in internal $R \& D$ among innovative companies. In the same period, pharmaceutical companies operating in Brazil increased $R \& D$ expenditure as part of their net revenues. Moreover, domestic companies like Aché, Biolab, Cristália, and Eurofarma, invested above the sector average 21. Despite advances, $R \& D$ spending in the Brazilian pharmaceutical industry falls far short of the $15 \%$ to $20 \%$ of net annual revenue spent by leading global companies, or even the $6 \%$ to $7 \%$ spent by Indian companies 32,33,34.

Table 3 shows that the number of companies that rely on external acquisition of $R \& D$ in Brazil also increased during the period, but without an increase in R\&D as a percentage of NSR. In 
Spending on key innovative activities by the Brazilian pharmaceutical industry.

\begin{tabular}{|c|c|c|c|c|c|}
\hline Activity/Year & $\begin{array}{c}\text { Number } \\
\text { ofcompanies that } \\
\text { invested }\end{array}$ & $\begin{array}{c}\text { Rate among } \\
\text { the innovative } \\
\text { companies (\%) }\end{array}$ & $\begin{array}{c}\text { Amount (BRL } \\
\text { thousands) }\end{array}$ & $\begin{array}{l}\text { Share of the total } \\
\text { invested } \\
\text { (\%) }\end{array}$ & $\begin{array}{c}\text { Percentage of } \\
\text { NSR (\%) }\end{array}$ \\
\hline \multicolumn{6}{|l|}{ Internal R\&D } \\
\hline 2008 & 144 & 48.00 & 430,982 & 29.00 & 1.40 \\
\hline 2011 & 137 & 65.00 & 920,709 & 50.00 & 2.40 \\
\hline \multicolumn{6}{|c|}{ Acquisition of external R\&D } \\
\hline 2008 & 59 & 20.00 & 187,336 & 13.00 & 0.60 \\
\hline 2011 & 67 & 32.00 & 219,009 & 12.00 & 0.60 \\
\hline \multicolumn{6}{|c|}{ Acquisition of other knowledge } \\
\hline 2008 & 34 & 11.00 & 40,805 & 3.00 & 0.10 \\
\hline 2011 & 28 & 13.00 & 19,057 & 1.00 & 0.05 \\
\hline \multicolumn{6}{|c|}{ Software acquisition } \\
\hline 2008 & 63 & 21.00 & 19,518 & 1.00 & 0.10 \\
\hline 2011 & 54 & 26.00 & 24,792 & 1.00 & 0.10 \\
\hline \multicolumn{6}{|c|}{ Acquisition of machinery and equipment } \\
\hline 2008 & 210 & 70.00 & 379,903 & 26.00 & 1.30 \\
\hline 2011 & 157 & 74.00 & 289,255 & 16.00 & 0.80 \\
\hline \multicolumn{6}{|l|}{ Training } \\
\hline 2008 & 157 & 52.00 & 15,436 & 1.00 & 0.10 \\
\hline 2011 & 92 & 44.00 & 59,827 & 3.00 & 0.20 \\
\hline \multicolumn{6}{|l|}{ Total } \\
\hline 2008 & 301 & - & $1,467,316$ & - & 4.90 \\
\hline 2011 & 211 & - & $1,849,037$ & - & 4.80 \\
\hline
\end{tabular}

R\&D: reserach and development; NSR: nominal net sales revenue.

Source: prepared by the authors based on data from Survey on Industrial Technological Innovation (PINTEC) 17,18 .

the innovation chain in drugs and medicines, the knowledge generated by external R\&D activities plays an important role in complementing internal capabilities. The degree of openness in R\&D appears to relate positively to pharmaceutical companies' innovation rate and commercial success 32 . Outsourcing of $R \& D$ activities is an increasingly important source for Brazilian pharmaceutical companies, given their limited technical and financial capability for the internal development of new products 35 .

A major increase occurred in spending on professional training, from 1\% (approximately BRL 15 million) to 3\% (BRL 59 million) of total investments in innovation during the period. Meanwhile, there was a decrease in the number of companies that invested in training, showing that the intensification of this source of innovation is concentrated in the largest companies.

There has also been a major drop in spending for acquisition of machines and equipment. Purchase of machinery is still the most prevalent innovation activity among companies in the sec- tor, but there has been a nominal drop in investments as a proportion of NSR. This indicator more than a change in innovation strategy, probably reveals a reduction in productive investments by Brazilian companies in a period characterized by strong appreciation of the Brazilian real. Rather than expanding production capacity, companies turned to imports to meet the growth in local demand. This perception is based on the recent increase in the sector's trade deficit.

Importantly, the diffusion of cutting-edge medicines on the Brazilian market is limited by rising $R \& D$ costs, directly impacting the final prices of new compounds. From this angle, new products obtained by biotechnology are particularly affected. For example, the mean cost of treating a patient with monoclonal antibodies can reach US\$ 200 thousand 36. Although the production of biosimilars holds promise for expanding access to more advanced therapies, copies are expected to cost $15 \%$ to $40 \%$ less than the reference drugs. Even so, due to the extremely high initial prices, this discount rate will be 
insufficient to guarantee broad access to given treatments $37,38,39$.

\section{Public policies for innovation}

In Brazil, government measures to foment innovation in drugs and medicines have been motivated historically by imbalances in the sector's balance of payments. Reducing the dependence on imports of pharmaceutical products has been a strategic objective of various industrial policies 40,41 . More recently, however, public policies have aimed at technological innovation in companies seeking to mitigate the financial risks associated with the initial product development stages.

In addition to commercial aspects, policies to stimulate internal $R \& D$ activities are justified by their potential sociopolitical and geographic impacts. The concentration of R\&D activities in a few countries and global companies has led to increasing abandonment of the more vulnerable segments of the population. Other authors 42 call attention to the fact that it is precisely the poorest and most underprivileged areas that have few or no health care options; and that even when they exist, the existing treatments are not necessarily accessible. The importance of each country's internal scientific effort is highlighted by the argument that different epidemiological profiles lead to different demands on the innovation systems 43 . Along the same line, authors 12 have highlighted the unfavorable position of less developed countries as a function of the lack of specific medicines for their populations' needs. Such issues reinforce the perception that the autonomy of productive segments in health is related to public policy sovereignty, among other areas of national development 44 .

The Brazilian Federal Government acts in financing innovation through the Program to Support the Development of the Health Industrial Complex (PROFARMA) and the Technological Fund (FUNTEC) of the National Economic and Social Development Bank (BNDES), providing funding for production, innovation, company restructuring, and exports. As of 2013, some 100 projects had been approved or were under analysis, totaling BRL 3 billion in financing. Additionally, the Financing Agency for Studies and Research (Finep) coordinates the economic subventions program, which, since its conception, has featured the concept of risk-sharing to favor innovation 7,45 .

The importance assigned by Federal Government programs to biotechnology and nanotechnology appears in the creation of exclusive credit channels offered by the principal funding agencies. PROFARMA, the CT-Biotec Sector Fund, and Finep's calls for bids for economic subventions earmark specific funding to foment innovations in biopharmaceuticals. Investments are supported for research, development, and related services, contemplating those needed to build intangible capital and physical infrastructure in the chain of R\&D and production of biotechnological products 46 .

As for demand polices, some important changes have occurred in the regulatory framework, like Law 12,715/2012, which allows waiving public tenders in the case of strategic technology transfers for the SUS, and Law 12,349/2010, which regulates government purchases as an instrument to open the market to domestic innovative products, allowing the application of a preference margin up to $25 \%$ for products manufactured by Brazilian companies without public bids, when the object of the purchase is the result of technological innovation 47 . In addition, recent years seen advances in the regulatory framework, described in detail in studies 14,27 focused on this analysis. There is also another line to this strategy involving action by the Brazilian Ministry of Health in managing the acquisition of medicines for the SUS, to cite another example. Centralization of purchases of strategic products within the National Policy for Pharmaceutical Assistance is linked to the proposal of the Industrial Development Policy (PDP) to use the state's purchasing power as a mechanism for stimulating innovation 48 .

\section{Final remarks}

This article has raised relevant questions for taking advantage of opportunities related to the expansion of generics and new technological trajectories for growth and innovation in Brazilian pharmaceutical companies. The advent of new technological routes based on biotechnology has altered the nature of technological barriers to market entry, reducing the relative importance of tacit knowledge and increasing the value of encoded knowledge as a source of innovation. Given the global reduction of productivity in fine chemical innovations, biopharmaceuticals present greater potential for Brazilian industry.

Meanwhile, the largest Brazilian companies have increased their efforts in capacity-building and innovation. This group has been responsible for nearly doubling $R \& D$ spending as a proportion of revenue, strengthening the role of this source of innovation. The increase in R\&D activities is probably associated with technological 
opportunities, greater capacity-building, and public policies for technological development, which have expanded the availability of financing, tax incentives, and government purchases.
In short, the Brazilian pharmaceutical industry is slowly and gradually moving towards the consolidation of its industrial base, greater technological capability, and intensification of $R \& D$ activities. This move has been mainly supported by growth in the domestic market, generics, and technological opportunities.

\section{Contributors}

P. B. Tigre contributed substantially to the study's conception, participating in the data analysis and interpretation, writing parts of the article and critically revising it, approving the final version for publication, and taking responsibility for the article's integrity, guaranteeing that any questions regarding precision or accuracy of any part be investigated and resolved appropriately. C. V. M. F. Nascimento and L. S. Costa contributed to the study's conception, participating in the data analysis and interpretation, writing parts of the article and critically revising it, approving the final version for publication, and taking responsibility for the article's integrity, guaranteeing that any questions regarding precision or accuracy of any part be investigated and resolved appropriately.

\section{Acknowledgments}

The authors wish to thank Brazilian National Research Council (CNPq; process n. 405077/2013-0) for supporting this research, as well as the Rio de Janeiro Federal University (UFRJ) and Sergio Arouca National School of Public Health, Oswaldo Cruz Foundation (ENSP/Fiocruz; project ENSP-007-LIV-07-5). 


\section{References}

1. Perez C. Technological change and opportunities for development as a moving target. CEPAL Review 2001; (75):109-29.

2. Christensen CM. The innovator's dilemma: when new technologies cause great firm to fail. Massachusetts: Harvard Business School Press; 1997.

3. Cesar A, Ma P, Singh N, Smith J. What's driving the recent surge in new drug approvals? Washington DC: McKinsey Center for Government; 2013.

4. Barbosa D. Uma introdução à propriedade intelectual. Rio de Janeiro: Lumen Juris ; 2003.

5. Quental C, Abreu JC, Bomtempo JV, Gadelha CAG. Medicamentos genéricos no Brasil: impactos das políticas públicas sobre a indústria nacional. Ciênc Saúde Coletiva 2008; 13:619-28.

6. Organisation for Economic Co-operation and Development (1997). The measurement of scientific and technological activities proposed guidelines for collecting and interpreting technological innovation data Oslo Manual European Commission Eurostat. 3Rd Ed. Paris: Organisation for Economic Co-operation and Development; 1997.

7. Palmeira Filho PL, Capanema LXL. A indústria farmacêutica nacional: desafios rumo à inserção global. In: Além AC, Fábio G, organizadores. O BNDES em um Brasil em transição. Rio de Janeiro: Banco Nacional de Desenvolvimento Econômico e Social; 2000. p. 307-17.

8. Gadelha CAG, Maldonado JMSV, Costa LS. O complexo produtivo da saúde e sua relação com o desenvolvimento: um olhar sobre a dinâmica da Inovação em Saúde. In: Giovanella L, Escorel S, Lobato LVC, Noronha JC, Carvalho AI, organizadores. Políticas e sistema de saúde no Brasil. Rio de Janeiro: Editora Fiocruz; 2012. p. 209-37.

9. Vargas MA, Ribeiro LC, Paiva L, Gadelha CAG. A inovação nos segmentos químicos e biotecnológicos da saúde: nichos estratégicos e lacunas. In: Costa LS, Bahia L, Gadelha CAG, organizadores. Saúde, desenvolvimento e inovação. v. 2. Rio de Janeiro: CEPESC Editora; 2015. p. 105-38.

10. Souza ALP, Pitassi C, Bouzada MAC, Gonçalvez AA. A rede brasileira de produção pública de medicamentos na perspectiva da gestão de cadeias de suprimentos: o papel das TIC. Rev Adm Pública 2015; 49:615-41.

11. Magalhães JL. Estratégia governamental para internalização de fármacos \& medicamentos em doenças negligenciadas [Doctoral Dissertation]. Rio de Janeiro: Escola de Química, Universidade Federal do Rio de Janeiro; 2011.

12. Oliveira EA, Labra ME, Bermudez J. A produção pública de medicamentos no Brasil: uma visão geral. Cadernos de Saúde Pública 2006; 22:2379-89.
13. Geremia F, Bianchi C, Stallivieri F, Geremia DS Adensamento tecnológico do sistema de saúde brasileiro: desafios para a política de comprar governamentais. In: Costa LS, Bahia L, Gadelha CAG, organizadores. Saúde, desenvolvimento e inovação. v. 2. Rio de Janeiro: CEPESC Editora; 2015. p. 301-25.

14. Vargas MA. Indústria de base química no Brasil: potencialidades, desafios e nichos estratégicos. In: Gadelha P, Gadelha CAG, Noronha JC, Pereira TR, organizadores. Brasil Saúde Amanhã: complexo econômico industrial da saúde. Rio de Janeiro: Editora Fiocruz; no prelo.

15. Martich E. A política de medicamentos genéricos e o mercado farmacêutico na Argentina e no Brasil [Masters Thesis]. Rio de Janeiro: Escola Nacional de Saúde Pública Sergio Arouca, Fundação Oswaldo Cruz; 2013.

16. Associação Brasileira das Indústrias de Medicamentos Genéricos. Pró genéricos. http://www.pro genericos.org.br/ (accessed on 20/May/2014).

17. Instituto Brasileiro de Geografia e Estatística. Pesquisa Industrial de Inovação Tecnológica PINTEC 2008. Rio de Janeiro: Instituto Brasileiro de Geografia e Estatística; 2008.

18. Instituto Brasileiro de Geografia e Estatística. Pesquisa Industrial de Inovação Tecnológica PINTEC 2011. Rio de Janeiro: Instituto Brasileiro de Geografia e Estatística; 2011.

19. Paranhos J. Interação entre empresas e instituições de ciência e tecnologia: o caso do sistema farmacêutico de inovação brasileiro. Rio de Janeiro: EdUERJ; 2012.

20. Costa LS, Gadelha CAG, Maldonado JMS, Santo M, Metten A. O complexo produtivo da saúde e sua articulação com o desenvolvimento socioeconômico nacional. Revista do Serviço Público 2013; 64:177-200.

21. Santos MCBG, Pinho M. Estratégias tecnológicas em transformação: um estudo da indústria farmacêutica brasileira. Gestão da Produção 2012; 19:405-18.

22. Palmeira Filho PL, Antunes A, Bomtempo JV. The pharmaceutical industry in Brazil: Is innovation the next step for the domestic industry? Chim Oggi 2012; 30:87-9.

23. Azevedo VF, Galli N, Kleinfelder A, D'Ippolito J, Urbano PC. Etanercept biosimilars. Rheumatol Int 2015; 35:197-209.

24. Agostini R. Biomedicamento terá parceria com Coreia. Folha de São Paulo 2013; 26 mar. http:// wwwl.folha.uol.com.br/fsp/mercado/100573biomedicamento-tera-parceria-com-coreia.shtml (accessed on 02/Oct/2014). 
25. Cristália: Cristália recebe aval da Anvisa em biossimilares. http://www.2cristalia.com.br/pdf/Cris talia-recebe-aval-da-Anvisa-em-biossimilares.pdf (accessed on 02/Oct/2014).

26. Magalhães JL, Antunes AMS, Boechat N. Laboratórios farmacêuticos oficiais e sua relevância para saúde pública do Brasil. RECIIS (Online) 2011; 5:85-99.

27. Gadelha CAG, Maldonado JMSV, Vargas MA, Barbosa PR, Costa LS. A dinâmica do sistema produtivo da saúde: inovação e complexo econômico-industrial. Rio de Janeiro: Editora Fiocruz; 2012.

28. Brito J, Vargas MA, Gadelha CAG, Costa LS. Competências científico-tecnológicas e cooperação universidade empresa na saúde. Rev Saúde Pública 2012; 46 Suppl 1:41-50.

29. Albuquerque EM, Cassiolato JE. As especificidades do sistema de inovação do setor saúde. Revista de Economia Política 2002; 22:134-51.

30. Gadelha CAG, Costa LS. Saúde e desenvolvimento no Brasil: avanços e desafios. Rev Saúde Pública 2012; 46 Suppl 1:13-20.

31. Schoenecker T, Swanson L. Indicators of firm technological capability: validity and performance implications. IEEE Transactions on Engineering Management 2002; 49:36-44.

32. Schuhmacher A, Germann P-G, Trill H, Gassmann O. Models for open innovation in the pharmaceutical industry. Drug Discov Today 2013; 18:1133-7.

33. Kale D. The distinctive patterns of dynamic learning and inter-firm differences in the Indian pharmaceutical industry. British Journal of Management 2010; 21:223-38.

34. Narula R, Kodiyat TP. How home country weaknesses can constrain further EMNE growth: extrapolating from the example of India. Reading: John Dunning Centre for International Business, Henley Business School, University of Reading; 2014. (Discussion Paper Number JHD-2014-01).

35. Berchicci L.Towards an open R\&D system: Internal $R \& D$ investment, external knowledge acquisition and innovative performance. Res Policy 2013; 42:117-27.

36. Shaughnessy AF. Monoclonal antibodies: magic bullets with a hefty price tag. BMJ 2012; 345:e8346

37. Walsh G. Biopharmaceutical benchmarks 2010. Nat Biotechnol 2010; 28:917-24.
38. Ahmed I, Kaspar B, Sharma, U. Biosimilars: impact of biologic product life cycle and European experience on the regulatory trajectory in the United States. Clin Ther 2012; 34:400-19.

39. Simoens S, Verbeken G, Huys I. Biosimilars and market access: a question of comparability and costs? Target Oncol 2012; 7:227-31.

40. Capanema LXL, Palmeira Filho PL. A cadeia farmacêutica e a política industrial: uma proposta de inserção do BNDES. BNDES Setorial 2004; 19: 23-48.

41. Gadelha CAG, Quental C, Fialho BC. Saúde e inovação: uma abordagem sistêmica das indústrias da saúde. Cad Saúde Pública 2003; 19:47-59.

42. Vidotti CCF, Castro LLC, Calil SS. New drugs in Brazil: do they meet Brazilian public health needs? Rev Panam Salud Pública 2008; 24:36-45.

43. Albuquerque EM, Souza SGA, Baessa AR. Pesquisa e inovação em saúde: uma discussão a partir da literatura sobre economia da tecnologia. Ciênc Saúde Coletiva 2004; 9:277-94.

44. Costa LS. Os serviços de saúde e a dinâmica de inovação do complexo econômico-industrial da saúde. In: Cunha FLAP, Lázaro CP, Pereira EBB, organizadores. Conhecimento, inovação e comunicação em serviços de saúde. Salvador: EdUFBA; 2014. p. 83-109.

45. Capanema LXL. Indústria farmacêutica brasileira e a atuação do BNDES. BNDES Setorial 2006; 23:193-216.

46. Banco Nacional de Desenvolvimento Econômico e Social. BNDES Profarma - biotecnologia. http:// www.bndes.gov.br/SiteBNDES/bndes/bndes_pt/ Institucional/Apoio_Financeiro/Programas_e_ Fundos/Profarma/profarma_biotecnologia.html (accessed em 02/Oct/2014).

47. Brasil. Lei no 12.349 de 15 de dezembro de 2010. Altera as Leis no 8.666, de 21 de junho de 1993 , 8.958, de 20 de dezembro de 1994, e 10.973, de 2 de dezembro de 2004; e revoga o $\$ 1$ o do art. 2 o da Lei no 11.273, de 6 de fevereiro de 2006. Diário Oficial da União 2010; 16 dez.

48. Reis C, Pieroni JP, Souza J. Biotecnologia para saúde no Brasil. BNDES Setorial 2010; 32:193-230.

49. As melhores empresas do Brasil em 2013. http:// exame.abril.com.br/negocios/melhores-e-maio res/2013/ (accessed on 13/Sep/2014). 


\section{Resumo}

A indústria farmacêutica brasileira caracteriza-se pela grande dependência de fontes externas de insumos, capital e tecnologia. O surgimento de oportunidades tecnológicas, associadas ao desenvolvimento da biotecnologia e ao fim do boom das patentes com o consequente avanço dos medicamentos genéricos, entretanto, vem abrindo janelas de oportunidades para a indústria local. Este artigo examina o comportamento inovador da indústria brasileira à luz dessas oportunidades, revelando que, embora o conjunto da indústria mantenha baixos níveis de investimentos em inovação, um pequeno grupo de grandes empresas nacionais vem ampliando sua participação no mercado e intensificando seus investimentos em pesquisa e desenvolvimento, apoiados por políticas públicas de inovação.

Indústria Farmacêutica; Medicamentos Genéricos; Desenvolvimento Sustentável; Inovação

\section{Resumen}

La industria farmacéutica brasileña se caracteriza por su gran dependencia de fuentes externas de insumos, capital y tecnología. El surgimiento de oportunidades tecnológicas, asociadas al desarrollo de la biotecnología, y al fin del boom de las patentes -con el consecuente avance de los medicamentos genéricos-, es paralelo a la apertura de ventanas de oportunidad para la industria local. Este artículo examina el comportamiento innovador de la industria brasileña a la luz de esas oportunidades, revelando que, aunque el conjunto de la industria mantenga bajos niveles de inversión en innovación, un pequeño grupo de grandes empresas nacionales está ampliando su participación en el mercado e intensificando sus inversiones en pesquisa y desarollo, apoyados por políticas públicas de innovación.

Industria Farmacéutica; Medicamentos Genéricos; Desarrollo Sostenible; Innovación
Submitted on $01 / \mathrm{Jul} / 2015$

Final version resubmitted on 23/Feb/2016

Approved on 23/Feb/2016 